\section{Potential of Croatian liquefied natural gas (LNG) terminal in supplying regional natural gas markets}

Rudarsko-geološko-naftni zbornik

(The Mining-Geology-Petroleum Engineering Bulletin) UDC: 662.7

DOI: $10.17794 / \mathrm{rgn} .2020 .4 .8$

Original scientific paper

\author{
Ivan Smajla'; Romana Crneković; Daria Karasalihović Sedlar'; Filip Božić3 \\ ${ }^{1}$ University of Zagreb, Faculty of Mining, Geology and Petroleum Engineering, Pierottijeva 6, 10000 Zagreb \\ ${ }^{2}$ Čulinečka cesta 31, 10040 Zagreb \\ ${ }^{3}$ Bernarda Vukasa 7, 10000 Zagreb
}

\begin{abstract}
This paper analyzes the possible role of liquefied natural gas (LNG) in the region in reducing carbon dioxide $\left(\mathrm{CO}_{2}\right)$ emissions by replacing a certain part of solid fossil fuels. Increasing natural gas consumption, declining North Sea natural gas reserves and increased natural gas production costs in Europe combined have created new opportunities for LNG in Europe. The Energy Strategy of Croatia is focused on intensifying the transit position for natural gas that could establish Croatia as a primary LNG market for countries from the region, which shows that the Energy Strategy supports LNG. Concerning LNG's introduction into the regional gas market, this paper analyses the possibility of establishing a regional gas hub. The region in this paper includes the following countries: Croatia, Serbia, Bosnia and Herzegovina, Hungary, Slovenia, and North Macedonia. On the other hand, the observed markets are not organized and sufficiently liquid, which is a crucial precondition for hub establishment. In order to decrease the region's dependence on pipeline natural gas, it is necessary to construct gas interconnections between Croatia - Serbia, Croatia - Bosnia and Herzegovina and Serbia - North Macedonia. With the mentioned interconnections, the region could achieve greater security of natural gas supply. This paper discusses the possibility of utilizing the full capacity of a LNG terminal as a source of natural gas supply for the purpose of replacing solid fossil fuels in the region's primary energy consumption. By replacing solid fossil fuels with natural gas, it is possible to achieve significant savings on $\mathrm{CO}_{2}$ emissions, which contributes towards a green and sustainable future.
\end{abstract}

\title{
Keywords:
}

liquefied natural gas (LNG); LNG terminal; gas interconnections; regional gas market supply; solid fossil fuels

\section{Introduction}

Natural gas is considered a key fuel source with the lowest carbon content among fossil fuels (Moryadee et al., 2014). Some authors even stress that cleaner and more versatile than other hydrocarbons, natural gas has never had a brighter future (Chandra, 2006). The role of liquefied natural gas (LNG) becomes more and more important as the construction of the LNG terminal in Croatia is approaching its end. At the same time, the importance of LNG in the security of gas supply in the region increases significantly (Nosić et al., 2017). The target region, besides Croatia, includes countries directly interested in the import of natural gas from the Croatian LNG terminal such as Serbia, Bosnia and Herzegovina, Hungary, Slovenia, and North Macedonia. Natural gas markets grow robustly, supported by broad-based demand and the increasing availability of gas, aided by the continuing expansion of LNG (BP, 2019). By 2030, the projected decrease in domestic European gas production

Corresponding author: Ivan Smajla

ivan.smajla@rgn.hr will result in a shortfall of $12 \%$ of the EU's gas demand (Eser et al., 2019). The International Energy Agency (2017) forecasts flat demand and an average annual decline of $-2.5 \%$ for European production. This adds up to a 34 billion cubic meters (bcm) deficit in the 2017-2022 period and possible more in the future (Sziklai et al., 2020). Increasing natural gas consumption, declining North Sea gas reserves, increased production costs due to more demanding reservoir and production conditions and the deregulation of European gas and electricity markets have created new opportunities for LNG in Europe (Veselić et al., 2011; Velić et al., 2016). The main source of alternative gas for Europe will be the global LNG market, which comprises a wide range of countries including the USA (Dickel et al., 2014). The potential for LNG exports from North America is one of the key variables in the matrix of an increasingly globalized gas supply and demand picture, although it will clearly interact with a number of other fundamental drivers as the dynamics of a new model for gas supply and pricing emerge (Handerson, 2012). The Energy Strategy of Croatia is focused on taking advantage of the geo-strate- 
gic position and opportunities of Croatia, and intensifying the transit position for natural gas that could establish Croatia as a regional energy hub, according to Croatian Energy Strategy (Karasalihović Sedlar et al., 2011). The LNG's contribution to the diversification of gas supplies in Europe is undisputed (Boersma, 2015). The construction of new LNG receiving terminals is likely to bring about an increase in the number of importers fostering competition among them and shrinking their margins among the value chain (Dorigoni and Portatadino, 2008). The world energy policy for mitigation of global climate change is directed towards the reduction of $\mathrm{CO}_{2}$ emission and therefore the consumption of natural gas in the region and gasification of the region would contribute to a reduction in $\mathrm{CO}_{2}$ emissions (Karasalihović Sedlar et al., 2018). Croatia ratified the United Nations Framework Convention and Climate Change (UNFCCC) $(\boldsymbol{U N}, 1992)$ in 1996, while Kyoto Protocol (UN, 1998) was ratified on 27 April 2007 (Karasalihović Sedlar et al., 2011). Kyoto Protocol assigned the legally binding numerical targets for a reduction of greenhouse gas emissions for industrialized countries of the world, that are to be achievement during the commitment period 2008 - 2012 (Gupta, 2016). The $21^{\text {st }}$ Conference of Parties, under the UNFCCC summit in Paris (COP21), which took place in December 2015, set a backdrop for large-scale mitigation action through Nationally-Determined Contributions (NDCs), prompting further research into the future of gas in a decarbonized Europe (Hickey et al., 2019). NDCs are national climate plans highlighting climate actions, including climate related targets, policies and measures which governments aims to implement in response to climate change and as a contribution to global climate action. Central to the NDCs is the concept of national determination. A presentation of the European Green Deal was held in December 2019. The European Green Deal represents the European action plan and response to climate change. It is a new growth strategy that aims to transform the European Union (EU) into a fair and prosperous society, with a modern, resource-efficient and competitive economy where there are no net emissions of greenhouse gases in 2050 and where economic growth is decoupled from resource use $(E C, 2019)$.

Natural gas is recognized as the most important energy source for the transition from a carbon to a low-carbon economy. Building gas interconnections between Croatia and neighboring countries, further gasification of the whole region and the significant increase in natural gas consumption in each country will increase the economic feasibility of the LNG terminal on the island of Krk, Croatia. The dependence of Central and SouthEastern Europe on the pipeline gas is high, with an extremely poor interconnection capacity of each gas system, which do not necessarily relate to other European countries. Many countries in Central and Eastern Europe (CEEC) consider the one-sided dependency on pipeline gas as a security problem that they place on top of their political agenda and as an important element in their relations with Russia (Austvik, 2016). The increased imports of LNG have beneficial impacts on European gas prices by exerting more market pressure on piped gas imports from Russia (Eser et al., 2019).

The challenges, but at the same time, the opportunities, arisen from the global climate change, environmental issues and energy geo-strategic position of Croatia, have led to a need for merging with the existing EU Energy Policies and present and future cooperation with neighboring countries, including countries of Southeast Europe. The future plan for the development of the Croatian energy sector includes estimates for energy demand with strategic goals, priority activities and technological, economic and environmental strategy effects (Karasalihović Sedlar et al., 2011). The construction of the LNG terminal would provide a higher security of the natural gas supply in the region and diversification of supply.

Important policy implications include the influence that the future LNG terminal in Croatia will have on the diversity and security of the supply of natural gas, a reduction of $\mathrm{CO}_{2}$ emission in the region, and an increase in employment and economic growth (Ruble, 2017). LNG as an alternative fuel can be fostered by stimulating demand, increasing the availability of LNG and improving the ecological effects of the fuel technology (Pfoser et al., 2018). The security of supply is the reason for the development and construction of the transport system because a reliable energy supply is a precondition for the economic development of the region. The gas transport system's capacity and connectivity with more routes of natural gas supply must be provided based on marketcompetitive prices. While one of the major suggestions of the new global climate change agreement is to reduce the use of fossil fuels by the year 2035, fossil fuels continue to play a leading role in the world energy mix. The share of oil and coal in the world's primary energy will continue to decrease, while only the share of natural gas will increase (Hlavaty, 2017).

In 2015, the Croatian government decided to include the project of the LNG terminal on the island of Krk, Croatia in the strategic investment list of Croatia because it is considered as a valuable project for the increase of diversity and security of supply in the region. The technical capacity of this LNG terminal will be 2.60 bcm per year (URL5). Concerning LNG introduction into the gas market, this paper analyses the importance of the Croatian LNG terminal and the possibility of establishing a regional gas hub.

Table 1 shows a comparison of annual capacities of the selected worldwide floating storage regasification unit (FSRU) terminals with the annual capacities of the FSRU terminal on the island of Krk, Croatia (URL3). The terminals' capacities expressed in TWh per year 
Table 1: Comparison of selected worldwide FSRU terminals annual capacities (IGU, 2017; URL3)

\begin{tabular}{|l|l|c|l|}
\hline Country & Name of the terminal & $\begin{array}{c}\text { Capacity } \\
\text { (bcm per } \\
\text { year) }\end{array}$ & $\begin{array}{l}\text { Capacity } \\
\text { (TWh/y) }\end{array}$ \\
\hline Italy & Livorno/LNG Toscana & 3.67 & 43.84 \\
\hline Kuwait & Mina Al - Ahmadi & 7.89 & 94.24 \\
\hline Brazil & Pecem & 8.16 & 97.47 \\
\hline Argentina & Bahia Blanca GasPort & 5.17 & 61.75 \\
\hline UAE & Dubai & 8.16 & 97.47 \\
\hline Lithuania & Klaipeda LNG & 4.08 & 48.73 \\
\hline Colombia & Cartagena LNG & 4.08 & 48.73 \\
\hline Croatia & Krk & 2.60 & 31.06 \\
\hline Turkey & Aliaga Etki & 5.00 & 59.72 \\
\hline Russia & Kaliningrad & 3.70 & 44.19 \\
\hline Turkey & Iskendurun & 7.30 & 87.19 \\
\hline Egypt & Sumed & 7.80 & 93.17 \\
\hline
\end{tabular}

were calculated with the gross calorific value of $43 \mathrm{MJ} /$ $\mathrm{m}^{3}$ which was obtained as the average gross calorific value of natural gas at all LNG liquefaction terminals in the world $($ GIIGNL, 2018).

\section{Existing and possible future gas interconnections in the region}

Currently, Croatia has gas interconnections with two countries, Slovenia (Rogatec) and Hungary (Dravaszerdahely), and both interconnections are designed to become bidirectional after the LNG terminal is built. LNG imports are a relevant asset to both Croatia and the EU in general, not only to cover peaks in demand but also to maintain competition in the gas sector (Naumenko, 2018). Serbia also has two interconnections, one with Hungary, named Kiskundorozsma and the other one at Zvornik with Bosnia and Herzegovina (URL1; Crneković, 2018). Possible flow directions and technical capacities of the mentioned existing interconnections are listed in Table 2.

Table 2: Possible flow directions and technical capacities of existing interconnections (URL1)

\begin{tabular}{|l|c|}
\hline Gas interconnection & $\begin{array}{c}\text { Capacity } \\
{[\text { GWh/d] }}\end{array}$ \\
\hline Rogatec (Slovenia $\longrightarrow$ Croatia) & 53.70 \\
\hline Dravaszerdahely (Hungary $\longrightarrow$ Croatia) & 78.30 \\
\hline Kiskundorozsma (Hungary $\longrightarrow$ Serbia) & 142.00 \\
\hline Zvornik (Serbia $\longrightarrow$ Bosnia and Herzegovina) & 18.00 \\
\hline
\end{tabular}

It is a fact that the dependence of the central and south-eastern European countries on Russian gas is high and that their gas systems are very poorly connected to each other. The 2009 Russia-Ukraine gas conflict brought more significant consequences such as severe economic damage and humanitarian crisis than most militarized interstate disputes (Lee, 2017). The Southern Corridor is an initiative by the European Commission to supply Europe with gas from the Caspian region and Middle Eastern countries. That corridor, which is primarily focused on bringing Caspian gas to Italy, could open up the possibility of connecting Albania with Croatia via the Ionian Adriatic Pipeline, which would also add to creating an interconnected gas network in southeastern Europe. The route consists of the South Caucasus Pipeline (SCP), the Trans Anatolian Pipeline (TANAP), the Trans Adriatic Pipeline (TAP), and the Ionian Adriatic Pipeline (IAP). The total length is approximately $3500 \mathrm{~km}$. The South Caucasus pipeline connects Baku in Azerbaijan with Erzurum in Turkey (Chang et al., 2013). Trans Anatolian Pipeline (TANAP) as a part of the Southern Corridor has significant implications for the transit security of the European Union and the domestic gas market of Turkey (Ozdemir et al., 2015). TANAP is the central part of the South Corridor that connects the SCP with the TAP. The strategic interest of Azerbaijan and Turkey is to consolidate the position of the European Union's natural gas supply. The length of TANAP is $1850 \mathrm{~km}$ and it will connect Erzurum, where SCP ends, with Kipoi in Greece, where the Trans Adriatic Pipeline will begin. TANAP will carry an initial volume of $16 \mathrm{bcm}$ per year of Azeri natural gas reaching 31 bcm per year by 2026 (Ruble, 2017). TAP connects to TANAP in Kipoi and ends in the port of Fier in Albania, then immerses in the Adriatic Sea to San Foce in Italy (Podimata, 2016). TAP is on the Projects of Common Interest's (PCI) list. The expected release of the pipeline into operation is 2020 . The capacity of the TAP will be $20 \mathrm{bcm}$ per year, which is, if necessary, also expandable (Akhundzada, 2015).

IAP would transport natural gas to Croatia, Montenegro, Albania, Serbia, Kosovo and Bosnia and Herzegovina. Albania, Montenegro, and Croatia signed an agreement on the realization of the Ionian Adriatic pipeline construction of a total capacity of $5 \mathrm{bcm}$ per year (Banovac et al., 2009). The pipeline route will start in the Albanian port Fier and will go to the Croatian port of Ploče, connecting the Croatian natural gas transport system with the Trans Adriatic Pipeline (TAP). This will represent a new natural gas supply and transit direction from the Caspian region and Iran to Europe (Karasalihović Sedlar et al., 2011). Since several countries are involved in the construction of the IAP, this complicates and prolongs the development of such a project. To achieve further diversification and strengthening of the security of the natural gas supply on time, Croatia has also decided to build an LNG terminal on the island of Krk, Croatia. The LNG terminal project on the island of Krk, Croatia is a new big supply potential and it was given the status of a priority project (Hlavaty, 2017). Part of the LNG project represents the construction of evacuation pipeline that will connect the LNG terminal with the current transport pipeline. In addition to the construction of the 


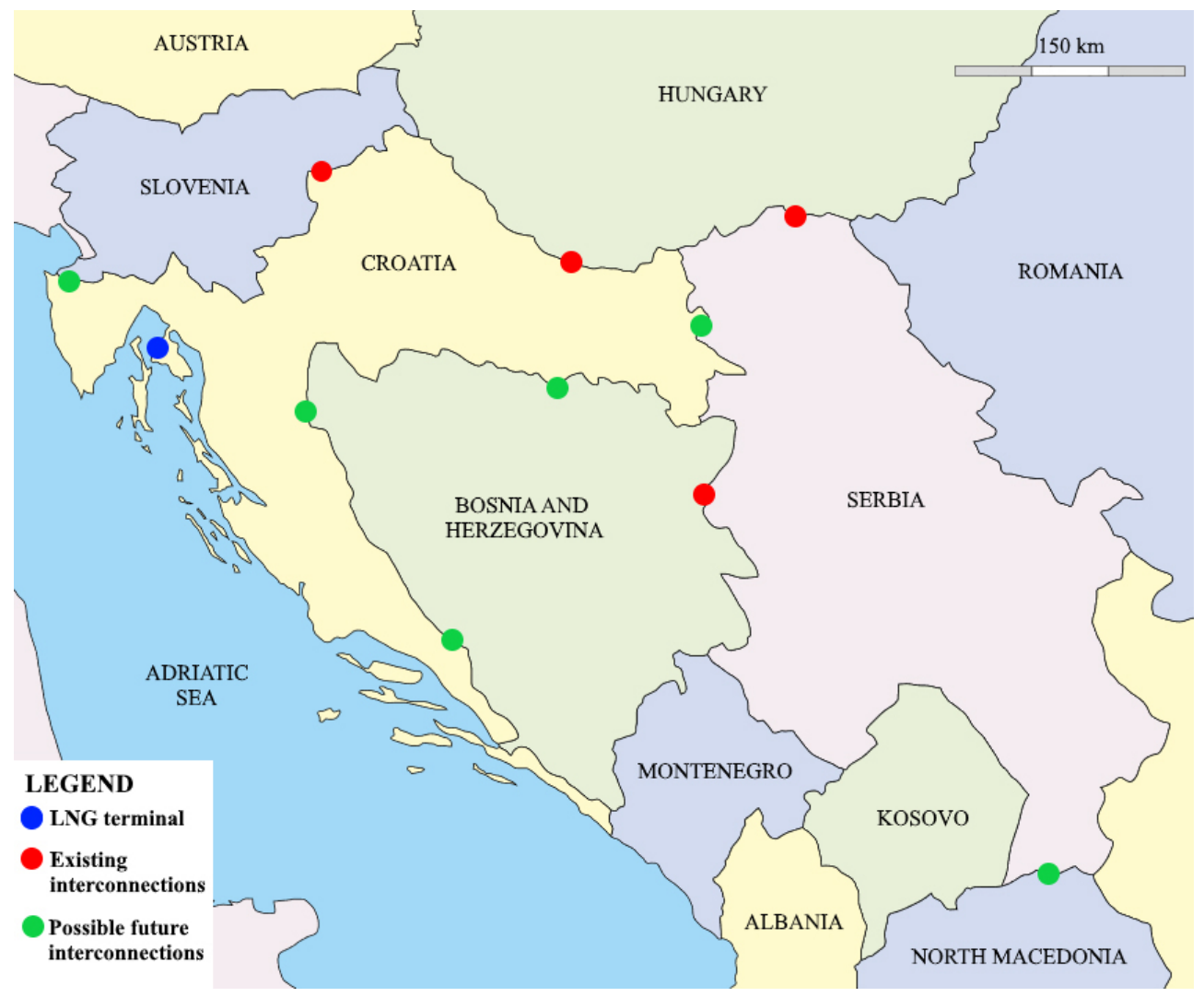

Figure 1: Existing and possible future interconnections in the region.

evacuation pipeline, it is also necessary to increase the capacity of transport routes to other countries in the region in order to allow natural gas exports. Because of this, it is necessary to build the following pipelines (Plinacro, 2017):

1) Omišalj - Zlobin gas pipeline that would connect the LNG terminal to the existing transport system.

2) Zlobin - Bosiljevo - Kozarac - Slobodnica gas pipeline that would allow the transport of additional quantities of natural gas to be transported to neighboring countries.

3) Slobodnica - Sotin gas pipeline that would connect the Croatian gas transport system to the border with Serbia.

As a part of transport system development in Croatia, besides the LNG evacuation pipeline, Plinacro is planning the construction of three interconnections between Croatia and Bosnia and Herzegovina. These three interconnections are: Slobodnica - Brod, Zagvozd - Imotski - Posušje and Rakovica - Tržac - Bihać. Interconnections Slobodnica - Brod and Imotski - Posušje will be profitable only if they connect to the central already existing gas pipeline in Bosnia and Herzegovina. The interconnections Zagvozd - Imotski - Posušje and Rakovica Tržac - Bihać are Plinacro projects which are on the Projects of Mutual Interest (PMI) list. The projected capacity for both interconnections is $73 \mathrm{GWh} / \mathrm{d}$ (Hlavaty, 2017).
In addition to the three interconnections with Bosnia and Herzegovina, interconnections with Serbia and Slovenia are also planned. Interconnection with Slovenia will be realized in Istria near the city of Umag, Croatia, for the purpose of achieving regional connectivity of the Croatian and Slovenian gas pipelines and the very important gasification of the wider area of the city and the port of Koper, Slovenia. For connecting Croatian and Serbian transport systems, there are two possibilities. One possibility is building the interconnection Osijek Sombor. Serbia has an existing gas pipeline close to its border with Croatia, but Croatia should build a pipeline from Osijek that would connect its pipeline to Sombor. Another option is the construction of the gas pipeline Slobodnica - Sotin - Bačko Novo Selo. Croatia has an existing gas pipeline to Sotin, but for Serbia, it is necessary to build a section of the pipeline from Bačko Novo Selo to Novi Sad. This interconnection with Serbia would be economically the most profitable for Croatia. The interconnection Sotin - Bačko Novo Selo is a project by Plinacro which is also on the PMI project list. The projected capacity for this interconnection is 205 $\mathrm{GWh} / \mathrm{d}$ (Hlavaty, 2017). Besides interconnection with Croatia, Serbia is also planning interconnection with North Macedonia that would be realized near Sopot. The projected capacity of this interconnection between Serbia and North Macedonia is $10.4 \mathrm{GWh} / \mathrm{d}$.

Figure 1 shows the geographical locations of interconnections in region. The red circles depict existing gas 
interconnections, the green circles depict possible future interconnections in the region and the blue circle depicts the future LNG terminal on the island of Krk, Croatia.

\section{LNG terminal capacity utilization analysis}

This chapter discusses the possibility of utilizing the full capacity of LNG terminals as the source of natural gas supply for the purpose of replacing solid fossil fuels in the region. By replacing solid fossil fuels with natural gas, it is possible to achieve significant savings on $\mathrm{CO}_{2}$ emissions, which will be presented later in this chapter. Also, this replacement does not require the construction of new large power plants, but it is achievable by the technological modification of existing plants. According to the data of the Statistical Office of the European Union - Eurostat, the consumption of solid fossil fuels in the observed region, according to the latest available data from 2018, was 188.81 TWh per year. Figure 2 shows the distribution of consumption by observed countries in the last 5 years (URL2).

By far the largest consumer of solid fossil fuels in the region is Serbia, followed by Bosnia and Herzegovina and Hungary. Of all the observed countries, the smallest consumer of solid fuels is Croatia, which also achieved the largest decline in consumption of solid fossil fuels. If the structure of consumption of solid fossil fuels is ob-

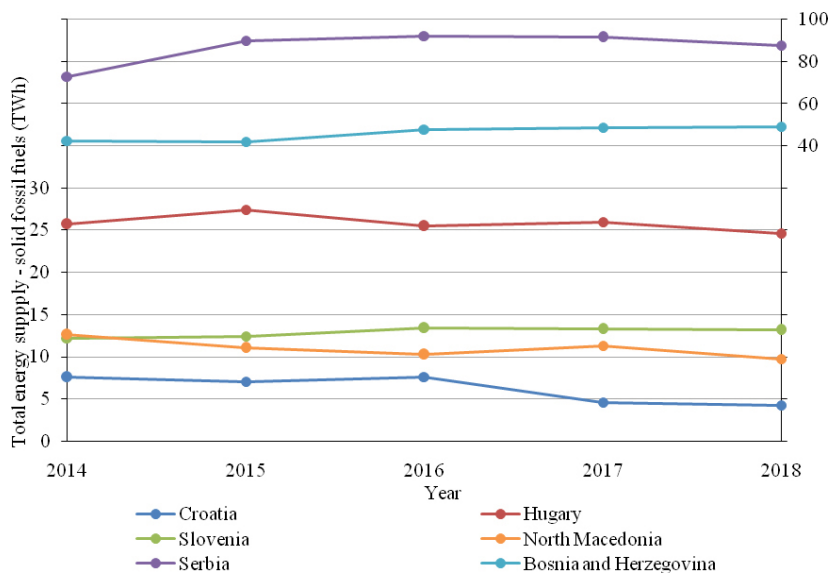

Figure 2: Consumption of solid fossil fuels in observed countries in the last 5 years (URL2) served lignite is the most used solid fossil fuel in all countries except Croatia, where other bituminous coal is the most used solid fossil fuel (URL2).

Since power plants using solid fossil fuels and power plants using gas in most cases have a very similar efficiency, the assumption used below is that one TWh of solid fossil fuels will be replaced by one TWh of natural gas. The LNG terminal on the island of Krk, Croatia with a maximum regasification capacity of $2.6 \mathrm{bcm}$ per year of natural gas or $31.06 \mathrm{TWh}$, enables the replacement of $16.45 \%$ solid fossil fuels used in 2018 with natural gas. Table 3 below shows the redistribution of natural gas to the observed countries in which the natural gas is evenly distributed depending on the consumption of solid fossil fuels. This means that the largest quantity of natural gas will be delivered to the largest consumer of solid fossil fuels, Serbia, then to Bosnia and Herzegovina, Hungary, etc.

In addition to the distribution of natural gas by country, Table 3 also shows the quantity of natural gas transported via interconnections expressed in terawatt hours per year $(\mathrm{TWh} / \mathrm{y})$. In this analysis, the starting point of redistribution is Croatia, i.e. the LNG terminal on the island of Krk, Croatia. After regasification of natural gas at the LNG terminal, the same is transported via the Croatian natural gas transport system to the interconnections with all the observed countries except Northern Macedonia. As mentioned earlier in Chapter 2, a prerequisite for this analysis is built interconnections of sufficient capacity with countries with which Croatia has a land border. This means that all the observed countries except Northern Macedonia will be able to transport natural gas via the shortest, simplest, and cheapest route to their transport system (only one interconnection). In the case of Northern Macedonia, natural gas is first transported via the interconnection Croatia - Serbia, and then Serbia - Northern Macedonia (two interconnections).

As mentioned earlier, natural gas is considered a transitional energy source mainly due to the fact that it can greatly reduce the use of solid fossil fuels which produce about 1.7 times higher $\mathrm{CO}_{2}$ emissions in comparison to natural gas. Replacing 31.06 TWh of solid fossil fuels with natural gas will result in significant savings on $\mathrm{CO}_{2}$ emissions in the region. The emission factors listed in

Table 3: Possibility of redistribution of natural gas from LNG terminal to region.

\begin{tabular}{|l|c|c|c|}
\hline Country & $\begin{array}{c}\text { Delivered natural gas from } \\
\text { LNG terminal (TWh/y) }\end{array}$ & Interconnection & $\begin{array}{c}\text { Imported natural gas via } \\
\text { interconnections (TWh/y) }\end{array}$ \\
\hline Croatia & 0.70 & & 4.06 \\
\hline Hungary & 4.06 & Croatia - Hungary & 2.16 \\
\hline Slovenia & 2.16 & Croatia - Slovenia & 16.04 \\
\hline Serbia & 14.44 & Croatia - Serbia & 8.09 \\
\hline Bosna and Herzegovina & 8.09 & Croatia - Bosnia and Herzegovina & 1.60 \\
\hline North Macedonia & 1.60 & Serbia - North Macedonia & $\mathbf{3 0 . 3 5}$ \\
\hline Total & $\mathbf{3 1 . 0 6}$ & & \\
\hline
\end{tabular}


Table 4: Emission reduction due to replacement of 31.06 TWh of solid fossil fuels with natural gas.

\begin{tabular}{|l|c|c|c|c|}
\hline Country & $\begin{array}{c}\text { Energy used } \\
(\mathbf{T W h})\end{array}$ & $\begin{array}{c}\text { Solid fossil fuel } \mathbf{C O}_{\mathbf{2}} \text { emissions } \\
\left(\mathbf{1 0 0 0} \text { tonnes of } \mathbf{C O}_{\mathbf{2}}\right)\end{array}$ & $\begin{array}{c}\text { Natural gas CO } \mathbf{2} \text { emissions } \\
\left(\mathbf{1 0 0 0} \text { tonnes of } \mathbf{C O}_{\mathbf{2}}\right)\end{array}$ & $\left.\begin{array}{c}\text { Emission reduction } \\
(\mathbf{1 0 0 0} \text { tonnes of } \mathbf{C O}\end{array}\right)$ \\
\hline Croatia & 0.70 & 238.97 & 141.56 & 97.41 \\
\hline Hungary & 4.06 & 1476.36 & 819.30 & 657.06 \\
\hline Slovenia & 2.16 & 787.83 & 437.20 & 350.63 \\
\hline Serbia & 14.44 & 5256.26 & 2916.93 & 2339.32 \\
\hline $\begin{array}{l}\text { Bosna and } \\
\text { Herzegovina }\end{array}$ & 8.09 & 2945.37 & 1634.52 & 1310.85 \\
\hline North Macedonia & 1.60 & 583.32 & 323.71 & 259.61 \\
\hline Total & & $\mathbf{1 1 2 8 8 . 1 0}$ & $\mathbf{6 2 7 3 . 2 2}$ & $\mathbf{5 0 1 4 . 8 8}$ \\
\hline
\end{tabular}

the Covenant of Mayors for Climate and Energy: Default emission factors for local emission inventories (Koffi et al., 2017) were used in the following calculation of emission reductions. The emission factor of lignite was chosen as the emission factor of solid fossil fuels for all countries (most used solid fossil fuel) except Croatia, where the emission factor of other bituminous coal was used. According to Covenant of Mayors for Climate and Energy (Koffi et al., 2017) and Intergovernmental Panel on Clime Change (URL4) standard denomination, emission factors for all fuels used in the analysis are:

- lignite - 0.364 tonnes of $\mathrm{CO}_{2}$ per MWh of used fuel

- other bituminous coal - 0.364 tonnes of $\mathrm{CO}_{2}$ per MWh of used fuel

- natural gas - 0.202 tonnes of $\mathrm{CO}_{2}$ per $\mathrm{MWh}$ of used fuel

Using these emission factors, Table 4 below shows the reduction of $\mathrm{CO}_{2}$ emissions in the case of the previously mentioned fuel change from solid fossil fuels to natural gas.

\section{Conclusions}

The construction of the LNG terminal in Croatia significantly increases the importance of LNG in the security of the gas supply in the analyzed region that includes the countries: Croatia, Serbia, Bosnia and Herzegovina, Hungary, Slovenia, and North Macedonia. The dependence of the region on natural gas as a fuel is high, especially the natural gas being delivered through standard, pipeline routes. Regional countries of the west Balkan area are not well connected with inter-state gas pipeline interconnections. Also, their organized markets are underdeveloped and the existing market liquidity is poor. Increasing natural gas consumption in the region and further gasification represents the beginning of the transition from a carbon economy to a low-carbon economy.

In the capacity utilization analysis, the possibility of replacing part of the solid fossil fuels in the region with a cleaner energy source, natural gas, was analyzed. The analysis implied that by using the full capacity of the LNG terminal, it is possible to replace $16.45 \%$ of the total consumption of solid fossil fuels in the observed countries. The largest quantity of natural gas should be delivered to Serbia, as the largest consumer of solid fossil fuels in the region, followed by Bosnia and Herzegovina, and so on. The analysis of redistribution of natural gas from the LNG terminal to the observed countries showed that the transport of natural gas to all countries except Northern Macedonia, will be possible via the shortest, simplest, and cheapest route passing only one interconnection. This analysis also showed that by using the full capacity of the LNG terminal for the already mentioned purposes, $\mathrm{CO}_{2}$ emissions in the region could be reduced by up to $5.014 \times 10^{6}$ tonnes per year.

The construction of the bidirectional capacity of interconnections with neighboring countries in the region must be Croatia's priority. This needs to be done in order to attain the infrastructure conditions for further development and for the rise of the liquidity of domestic markets for each analyzed country. Implementation of the EU legislation and the introduction of the local spot markets for natural gas will further contribute to the development of the integrated regional gas market.

\section{Acknowledgement}

All reports listed in the references are publicly available.

\section{References}

\section{Papers:}

Austvik O.G. (2016): The Energy Union and security-of-gas supply. Energy Policy, 96, 372-382. https://doi.org/10.1016 /j.enpol.2016.06.013

Akhundzada E. (2015): Energy Security in South East Europe: The Role of the Southern Gas Corridor, ISPI, Analysis No. 282.

Banovac E., Babić G., Pavlović D. (2009): Development of the natural gas infrastructure of the Republic of Croatia and its possible impacts on the security of the natural gas supply of the South East Region of Europe. 5th European Conference on Economics and Management of Energy in Industry, Conference Paper, ISBN: 978-972-99309-4-2. 
Chang C-P., Berdiev A. N., Lee C-C. (2013): Energy exports, globalization and economic growth: The case of South Caucasus. Economic Modelling 2013, 33(c), 333-346. https://doi.org/10.1016/j.econmod.2013.04.027

Dorigoni S., Portatadino S. (2008): LNG development across Europe: Infrastructural and regulatory analysis. Energy Policy, 36 (9), 2266-3373. https://doi.org/10.1016/j.enpol.2008.05.015.

Eser P., Chokani N., Abhari R (2019): Impact of Nord Stream 2 and LNG on gas trade and security of supply in the European gas network of 2030. Applied Energy, 238; 816830. https://doi.org/10.1016/j.apenergy.2019.01.068

Gupta A. (2016): Chapter 1 - Climate Change and Kyoto Protocol: An Overview. Handbook of Environmental and Sustainable Finance, 3-23. https://doi.org/10.1016/B978-012-803615-0.00001-7

Hickey C., Deane P., McInerney C., O Gallachoir B. (2019): Is there a future for the gas network in a low carbon energy system?. Energy Policy, 126, 480-493. https://doi. org/10.1016/j.enpol.2018.11.024

Lee Y. (2017): Interdependence, issue importance, and the 2009 Russia-Ukraine gas conflict. Energy Policy, 102, 199-209. https://doi.org/10.1016/j.enpol.2016.11.038

Karasalihović Sedlar D., Dekanić I., Hrnčević L. (2011): Recommendations for implementation of energy strategy of the Republic of Croatia. Energy, 36(7), 4191-4206. https:// doi.org/10.1016/j.energy.2011.04.024

Karasalihović Sedlar D., Vulin D., Jukić L., Smajla I. (2018): Possibility of decreasing $\mathrm{CO}_{2}$ emissions from flaring on a mature oil field. Journal of Petroleum Science and Engineering, 171, 1302-1308. https://doi.org/10.1016/j.petrol.2018.08.026

Moryadee S., Gabriel S. A., Avetisyan H. G. (2014): Investigating the potential effects of U.S. LNG exports on global natural gas markets. Energy Strategy Reviews, 2 (3-4), 273-288. https://doi.org/10.1016/j.esr.2013.12.004.

Nosić, A., Karasalihović Sedlar, D., Jukić, L. (2017): Terminska i opcijska tržišta ugljikovodika. Rudarsko-geološkonaftni zbornik (The Mining-Geology-Petroleum Engineering Bulletin), 32, 4, 45-54. https://doi.org/10.17794/rgn. 2017.4.5

Ozdemir V., Yavuz H.B., Tokgoz E. (2015) The Trans-Anatolian Pipeline (TANAP) as a unique project in the Euroasian gas network: A comparative analysis. Utilities Policy, 27, 97-103. https://doi.org/10.1016/j.jup.2015.06.007

Pfoser S., Schauer O., Costa Y. (2018): Acceptance of LNG as an alternative fuel: Determinants and policy implications. Energy Policy, 120, 259-267. https://doi.org/10.1016/j.enpol.2018.05.046.

Podimata M. (2016): Methodological approach to EIA due to gas pipeline failure after an earthquake. The case study of the Trans Adriatic Pipeline. Journal of Natural Gas Science and Engineering, 35(A), 1200-1206. https://doi.org/ 10.1016/j.jngse.2016.09.043

Ruble I. (2017): European Union energy supply security: The benefits of natural gas imports from the Eastern Mediterranean, Energy Policy, 105, 341-353. https://doi.org/ 10.1016/j.enpol.2017.03.010

Sziklai B. R., Kóczy L. Á., Csercsik D. (2020): The impact of Nord Stream 2 on the European gas market bargaining po- sitions. Energy Policy, 144, 111692. https://doi.org/10.1016 /j.enpol.2020.111692.

Velić, J., Kišić, K., i Krasić, D. (2016): The characteristics of the production and processing of oil and natural gas in Croatia from 2000 to 2014. Rudarsko-geološko-naftni zbornik (The Mining-Geology-Petroleum Engineering Bulletin), 31, 2, 69-90. https://doi.org/10.17794/rgn.2016.2.6

Veselić M., Karasalihović Sedlar D., Hrnčević L. (2011): LNG regasification terminals access capacity analysis for security of European natural gas supply. Rudarsko-geološkonaftni zbornik, 23, 25-38.

\section{Books/thesis:}

Boersma T. (2015): Energy Security and Natural Gas Markets in Europe. Routledge, London, UK, 212 p.

Chandra V. (2006): Fundamentals of Natural Gas: An International Perspective. Pennwell Books, Tulsa, Oklahoma, USA, $280 \mathrm{p}$.

Crneković R. (2018): Possibilities of LNG terminal capacity utilization in the Republic of Croatia for decarbonisation of the energy sector in the region, Master's thesis, Faculty of mining, geology and petroleum engineering, Zagreb, Croatia, 56 p. (in Croatian)

\section{Reports (publicly available):}

British Petroleum (BP) (2019): BP Energy Outlook. BP p.l.c., London, UK, 73 p., https://www.bp.com/content/dam/bp/ business-sites/en/global/corporate/pdfs/energy-economics/energy-outlook/bp-energy-outlook-2019.pdf

Dickel R., Hassanzadeh E., Henderson J., Honoré A., El-Katiri L, Pirani S., Rogers H., Stern J., Yafimava K. (2014): Reducing European Dependence on Russian Gas: distinguishing natural gas security from geopolitics. Oxford Institute for Energy Studies, Oxford, UK, 87 p., https://www. oxfordenergy.org/wpcms/wp-content/uploads/2014/10/ NG-92.pdf

European Commission (EC) (2019): COMMUNICATION FROM THE COMMISSION TO THE EUROPEAN PARLIAMENT, THE EUROPEAN COUNCIL, THE COUNCIL, THE EUROPEAN ECONOMIC AND SOCIAL COMMITTEE AND THE COMMITTEE OF THE REGIONS - The European Green Deal. Publications Office of the European Union, Brussels, Belgium 24p., https://eurlex.europa.eu/resource.html?uri=cellar:b828d165-1c2211ea-8c1f-01aa75ed71a1.0002.02/DOC_1\&format $=$ PDF

GIIGNL (2018): The LNG industry GIIGNL Annual Report 2018. GIIGNL, Neuilly sur Seine, France, 28 p., https:// giignl.org/sites/default/files/PUBLIC_AREA/About_ LNG/5_LNG_Markets_And_Trade/giignl_2018_annual_ report.pdf

Handerson J. (2012): The Potential Impact of North American LNG Exports. Oxford Institute for Energy Studies, Oxford, UK, 65 p. https://www.oxfordenergy.org/wpcms/wpcontent/uploads/2012/10/NG-68.pdf

IGU (International Gas Union) (2017): World LNG Report. IGU, Barcelona, Spain, 100 p., https://www.igu.org/app/ uploads-wp/2017/04/103419-World_IGU_Report_FINAL_LR.pdf 
Koffi B., Cerutti A.K., Duerr M., Iancu A., Kona A., JanssensMaenhout G. (2017): Covenant of Mayors for Climate and Energy: Default emission factors for local emission inventories. Publications Office of the European Union, Luxembourg, EU, 56 p., https://publications.jrc.ec.europa.eu/repository/bitstream/JRC107518/jrc_technical_reports_com_default_emission_factors-2017.pdf

Naumenko, D. (2018): Russian gas transit through Ukraine after Nord Stream 2: Scenario analysis. Ukrainian Centre for European Policy, Konrad-Adenauer-Stiftung Ukraine, Kyiv, Ukraine, 24 p., https://www.kas.de/documents/ 270026/0/Russian+gas+transit+through+Ukraine+after+ NS2.+Scenario+Analysis.pdf/

Hlavaty V. (2017): Desetogodišnji plan razvoja plinskog transportnog sustava Republike Hrvatske. Plinacro, Zagreb, Croatia, 91 p., https://www.plinacro.hr/UserDocsImages/ dokumenti/Desetogodi\%C5\%A1 nji\%20plan\%20razvoja\%20PTS\%202018-2027.pdf

Plinacro (2017): Rules for carrying out the binding phase of the Open Season procedure. Plinacro, Zagreb, Croatia, 39 p. https://www.plinacro.hr/UserDocsImages/Open $\% 20$ season/Obvezuju\%C4\%87a\%20faza/ENGLESKI/Rules\% 20 for $\% 20$ carrying $\% 20$ out $\% 20$ the $\% 20$ binding $\% 20$ phase $\% 20$ of $\% 20$ the $\% 20$ Open $\% 20$ Season $\% 20$ procedure_publication1.pdf

United Nations (UN) (1992): United Nations Framework Convention on Climate Change. United Nations, New York,
USA, 25 p., https://unfccc.int/resource/docs/convkp/conveng.pdf

United Nations (UN) (1998): Kyoto protocol to the United Nations framework convention on climate change. United Nations, Kyoto, Japan, 21 p., https://unfccc.int/resource/ docs/convkp/kpeng.pdf

\section{Internet sources:}

URL1: ENTSOG (2019): The European natural gas network 2019. URL: https://entsog.eu/sites/default/files/2019-10/ ENTSOG_CAP 2019 A0 1189x841 FULL 400.pdf (accessed 30.7.2020.)

URL2: Eurostat (2020): Energy statistic - complete database. URL: https://ec.europa.eu/eurostat/web/energy/data/database (accessed 29.7.2020.)

URL3: Gas Infrastructure Europe (GIE) (2019): LNG Map 2019. URL: https://gie.eu/download/maps/2019/GIE LNG_2019_A0_1189x841_FULL_Final3.pdf (accessed 30.7.2020.)

URL4: Intergovernmental Panel on Clime Change (IPCC) (2006): Guidelines for National Greenhouse Gas Inventories. URL: https://www.ipcc-nggip.iges.or.jp/public/2006 $\mathrm{gl} /$ (accessed 1.8.2020.)

URL5: LNG Hrvatska (2020): LNG Hrvatska - O terminal. URL: https://lng.hr/o-terminalu (accessed 21.5.2020.) 


\section{SAŽETAK}

\section{Potencijal hrvatskoga terminala za ukapljeni prirodni plin (UPP) u opskrbi regionalnih tržišta prirodnoga plina}

Ovaj rad analizira moguću ulogu ukapljenoga prirodnog plina (LNG) u regiji u smanjenju emisije CO zamjenom određenoga dijela krutih fosilnih goriva. Povećana potrošnja prirodnoga plina, smanjenje rezervi plina u Sjevernome moru i povećani troškovi proizvodnje stvorili su nove mogućnosti za UPP u Europi. Energetska strategija Republike Hrvatske usmjerena je na jačanje tranzitne pozicije prirodnoga plina koja bi mogla uspostaviti Hrvatsku kao primarno tržište UPPa za zemlje iz regije, što pokazuje da je energetska strategija naklonjena UPP-u. U ovome radu provedena je analiza mogućnosti uspostave regionalnoga plinskog čvorišta za UPP. Regija obuhvaća sljedeće promatrane i ispitivane zemlje: Hrvatsku, Srbiju, Bosnu i Hercegovinu, Mađarsku, Sloveniju i Sjevernu Makedoniju. Ovisnost regije o plinu koji se isporučuje plinovodima velika je, a plinski transportni sustavi zemalja u regiji nisu dovoljno povezani s interkonekcijama, tako da prirodni plin može biti dostupan u dovoljnoj količini i kretati se između trgovaca. S druge strane, promatrana tržišta nisu organizirana i u dovoljnoj mjeri likvidna, što je ključni preduvjet za bilo koju vrstu čvorišta uopće. Da bi se smanjila ovisnost regije o plinovodnome prirodnom plinu, potrebno je izgraditi interkonekcije između Hrvatske i Srbije, Hrvatske i Bosne i Hercegovine te Srbije i Sjeverne Makedonije. Nakon dovršetka spomenutih interkonekcija regija bi mogla postići veću sigurnost opskrbe prirodnim plinom. Ovaj rad također analizira mogućnost korištenja punoga kapaciteta LNG terminala kao izvora opskrbe prirodnim plinom u svrhu zamjene krutih fosilnih goriva u regiji. Zamjenom krutih fosilnih goriva prirodnim plinom moguće je postići znatne uštede na emisiji $\mathrm{CO}_{2}$, što pridonosi zelenoj i održivoj budućnosti.

\section{Ključne riječi:}

ukapljeni prirodni plin (UPP), UPP terminal, plinske interkonekcije, regionalna plinska tržišta plina, kruta fosilna goriva

\section{Author(s) contribution}

Ivan Smajla (1) (mag. ing. petrol, teaching assistant, doctoral study) participated in the conceptualization of the work, visualized several figures and tables, participated in writing individual chapters and edited the paper. Romana Crneković (2) (mag. ing. petrol, gas distribution engineer), collected data about future interconnections, participated in writing all versions of the paper, collected data on LNG terminals and visualized several figures and tables. Daria Karasalihović Sedlar (3) (PhD full professor) devised the concept of the paper, participated in the writing of several chapters, researched multiple sources of literature and made some conclusions of the paper. Filip Božić (4) (mag. ing. petrol, senior gas trade expert) analysed the interconnections in the region, collected interconnection data, participated in the writing of certain chapters and made some conclusions of the paper. 